\title{
Potential of probiotics Bacillus subtilis to reduce ammonia levels, Vibrio $s p$ abundance, and increased production performance of Seaworm (Nereis sp) under laboratory scale
}

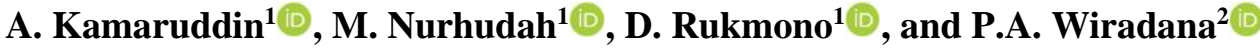 \\ ${ }^{1}$ Department of Aquaculture, Faculty of Utilization Fisheries Resources, Jakarta Fisheries University, Jakarta, ${ }^{2}$ Study \\ Program of Biology, Faculty of Health, Science, and Technology, Dhyana Pura University, Bali, Indonesia
}

Article information

Article history:

Received September 19, 2020

Accepted February 27, 2021

Available online October 1, 2021

\section{Keywords:}

Nereis $s p$

Seaworms

Probiotic agent

Bacillus subtilis

Aquaculture

Correspondence:

A. Kamaruddin

adityakamaruddin81@gmail.com

\begin{abstract}
This study aims to determine the potential of Bacillus subtilis probiotic in reducing levels of ammonia, Vibrio sp, and increased production performance in seaworm cultivation (Nereis sp.) under laboratory scale. Observation of the performance of seaworms (Nereis sp.) was carried out every 10 days which included weight gain $(\mathrm{gr})$, length $(\mathrm{cm})$, total biomass (gr), total bacteria (CFU/mL), total Vibrio sp. (CFU/mL), and total Bacillus subtilis $(\mathrm{CFU} / \mathrm{mL})$. Water quality measurements include temperature, dissolved oxygen (DO), $\mathrm{pH}$, ammonia, and total organic matter (TOM). Application of probiotics Bacillus subtilis has the potential to reduce ammonia concentration, increase growth, and reduce the abundance of Vibrio sp under laboratory-scale seaworm cultivation. P3 treatment $(0.01 \mathrm{~mL}$ with a probiotic density of $10^{6} \mathrm{CFU} / \mathrm{mL}$ ) gave the best results by being able to reduce the ammonia concentration by $47.5 \%$. In summary, the probiotic application using the bacteria Bacillus subtilis with different densities able to provide good results in supporting production performance, maintaining the abundance of Vibrio sp., and reducing ammonia concentration in seaworm cultivation. This is the first study to report the performance of seaworm production using probiotic agent, research is still needed to determine the digestive enzyme activity of seaworms given probiotics.
\end{abstract}

DOI: 10.33899/ijvs.2021.128408.1572, ()Authors, 2021, College of Veterinary Medicine, University of Mosul.

This is an open access article under the CC BY 4.0 license (http://creativecommons.org/licenses/by/4.0/).

\section{Introduction}

Polychaeta is one of the natural foods used in hatcheries as shrimp broodstock besides squid, shellfish, and commercial feed. The nutritional content of Polychaeta is higher when compared to other natural food sources so that Polychaeta worms are widely used as natural food for broodstock. Seaworms (Nereis sp.) is one type of Polychaeta worms which contain $56.29 \%$ protein, and $11.32 \%$ fat (1). The steroid hormones contained in this type of seaworm play an important role in the reproduction of shrimp broodstock (2). The use of seaworm as shrimp feed, has been widely researched, especially in the process of ripening gonads and spawning of broodstock. Previous research reported the success of laboratory-scale Dendronereis pinnaticirris hatchery which has produced larvae up to young worms that are ready to be used as natural shrimp feed (3). The availability of natural food in cultivation activities is very important, therefore seaworms cultivation needs to be done to provide natural food and efforts to maintain availability in nature. Cultivation of scrambled worms has not developed much in Indonesia due to limited research on aspects of biology, ecology, reproduction, and aspects of mass cultivation as well as economic aspects. The problem that also arises in Polychaeta cultivation is the high ammonia content in maintenance caused by the accumulation of organic material from the feed and metabolism, the inorganic nitrogen compounds produced are in the form of $\mathrm{NH}_{3}-\mathrm{N}$ and $\mathrm{NH}_{4}+$ which are toxic compounds for aquatic biota (4). The use of probiotics as a biological approach to water quality 
management by utilizing bacterial activity in remodeling organic matter in cultivation systems. The bioremediation agent must have the metabolic ability for oxidation, ammonification, nitrification, denitrification, sulfurization, and nitrogen fixation reactions so that it can directly overhaul organic and hazardous materials in the aquaculture systems (5). On the other hand, the use of natural-derived Polychaeta for cultivation purposes has decreased for biosecurity reasons (6). Polychaeta is benthic microfauna in shrimp and sediment ponds found in coastal areas. Polychaeta collected from nature may carry pathogens as well as viruses in the digestive tract by consuming sediment (7). Sediment can act as a habitat, vector and growth of pathogens such as Vibrio sp. and WSSV (White Spot Syndrome Virus) (8) therefore Polychaeta can act as an infectious host if given as natural food. The spread of Vibrio sp. in shrimp through several ways, namely through the feed, wounds on the body surface, and gills that cause bacteria to pass through the epithelial tissue and form colonies. Polychaeta plays a role in the spread of Acute Hepatopancreas Necrosis Disease (AHPND) which is caused by Vibrio parahaemolyticus and Hepatopancreatic Microsporidiosis caused by Microsporidian Enterocytozoon hepatopenaei (EHP) microspores (9). Probiotics can be used as a disease biocontrol agent in aquaculture and as an effort to reduce the antibiotic application (10). Bacillus sp. are lactic acid bacteria which can act as antagonistic bacteria to pathogens and reduction of Vibrio sp. in shrimp farming. Probiotics containing Bacillus sp. also aimed to improve growth performance in aquaculture. According to reports from several studies stated that Bacillus sp. can be widely used as microorganisms in probiotics to increase survival, growth and stimulate immunity in shellfish aquaculture.

Based on this, the purpose of this study was to determine the potential of probiotics Bacillus subtilis in reducing levels of ammonia, Vibrio sp, and production performance of seaworms (Nereis sp.) on a laboratory scale.

\section{Materials and methods}

\section{Time and research location}

This research was conducted from January to April 2020 at the Center for Brackish Water Fisheries. The use of premises, tools, and various facilities has obtained permission from the parties concerned and has followed various Standard Operating Procedures (SOP). The use of seaworm test animals (Nereis sp.) is intended only for laboratory-scale research.

\section{Research design}

The research design used a completely randomized design (CRD) with 4 treatments and 3 replicates. The probiotic used was pure isolate Bacillus subtilis with the addition of $10 \mathrm{ml}$ of Molasses/treatment as a nutrient for bacteria. Treatment were as follows: P1: with the bacterial density of $10^{10}$ was given as much as $50 \mathrm{ml}$. P2: with the bacterial density of $10^{8}$ was given as much as $10 \mathrm{ml}$. P3: with the bacterial density of $10^{6}$ was given as much as $0.01 \mathrm{ml}$. D: control (without probiotic Bacillus subtilis). Plastic-based seaworm rearing container with one drain outlet on the front side of the container with a diameter of $2 \mathrm{~cm}$. The container used has dimensions $\mathrm{L} \times \mathrm{W} \times \mathrm{H}(60 \mathrm{~cm} \times 30 \mathrm{~cm} \times 25 \mathrm{~cm})$ with a maximum volume of 45 liters. Aeration is given as much as 2 pieces in each container used. Before use, each container was cleaned using water containing $10 \mathrm{mg} / \mathrm{l}$ chlorine. The water medium is stored in a round container with a diameter of $1.5 \mathrm{~m}$, a height of $1.5 \mathrm{~m}$, and a maximum volume of 2.64 $\mathrm{m}^{3}$ and then sterilized using chlorine $25 \mathrm{mg} / \mathrm{l}$ (Figure 1).

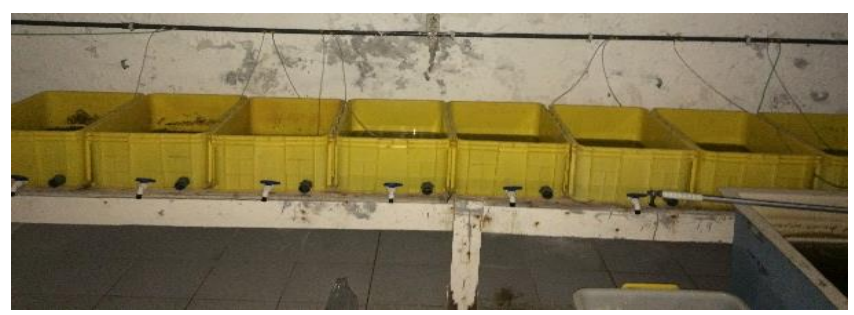

Figure 1: The seworms (Nereis sp.) rearing container used in this study.

\section{Substrate preparation and maintenance medium for seaworm}

The source of maintenance water comes directly from the sea which has been stored in the main reservoir with salinity ranging from 28-30 ppt. Water to be used during maintenance requires a low salinity ranging from 18-22 ppt, dilution is required until the salinity is in the range. Water needs as much as 20 liters/container. The substrate used as a medium for seaworms is in the form of live fine sludge obtained from seaworm cultivators. The substrate was then dried and weighed as much as $25 \mathrm{~kg} /$ container. The ready substrate is soaked in seawater in each container for 7 days so that the substrate texture is softer. The substrate height is $10 \mathrm{~cm}$ and the water level is $3 \mathrm{~cm}$ calculated from the substrate surface. Water changes are carried out every 10 days with a percentage of $40 \%$ (3).

\section{Preparation of seaworm (Nereis sp.)}

Seaworms (Nereis sp.) are obtained through collectors in living conditions with a weight ranging from $0.69 \mathrm{~g}-1.26 \mathrm{~g}$ and a length of $5.6-14.5 \mathrm{~cm}$ with a stocking density of 40 individuals/container. Worms are selected according to the criteria, namely: intact and unbroken limbs. The experimental animals were acclimatized for two weeks in a plastic box measuring $\mathrm{L} \times \mathrm{W} \times \mathrm{H}(60 \mathrm{~cm} \times 30 \mathrm{~cm} \times 25 \mathrm{~cm})$ which already contained fine mud and seawater substrate (3), salinity 28-30 ppt, and equipped with aerator equipment to meet the oxygen needs of the worm. Maintenance is carried out for 30 days in a controlled room. The feed used is commercial feed with a protein content of $48 \%, 9 \%$ fat, and $2.5 \%$ fiber. The dose of feed given is $3 \%$ of the worm biomass. The frequency of feeding was twice, carried out at 
06.00 am and $17.00 \mathrm{pm}$, the dead worms were removed and recorded for biomass and population calculations.

\section{Isolation of probiotic bacteria}

The pure isolate of Bacillus subtilis obtained from the intestines of milkfish (Chanos chanos). Each sample of $1 \mathrm{~g}$ was suspended in $3 \mathrm{ml}$ of $\mathrm{NaCl}$ solution (Sigma-Aldrich, US) $0.9 \%$, then put into a test tube containing $9 \mathrm{ml}$ of Tryptic Soy Broth (TSB) (Oxoid, Canada) and incubated for 24 hours at $30^{\circ} \mathrm{C}$, followed by incubation at $45^{\circ} \mathrm{C}$ for 10 minutes in the oven to activate the sporulation process. Ethanol 50\% (Sigma-Aldrich, US) was added as much as $20 \mathrm{ml}$ to each sample then incubated again at a lower temperature of $20^{\circ} \mathrm{C}$ for 1 hour, then centrifuged at $10.000 \mathrm{rpm}$. The supernatant produced was poured and incubated at $105^{\circ} \mathrm{C}$ in an oven for 5 minutes. Dry pellets were dissolved in $20 \mathrm{ml}$ of sterile physiological saline and diluted serially to $10^{-4}$ in $10^{-1}$ increments. A total of $0.1 \mathrm{ml}$ from each dilution series was spread in a Petri dish (Fisher Scientific, US) containing Tryptone Soya Agar (TSA) (Oxoid, Canada) which had been added with Polymyxin B antibiotic (Oxoid, Canada) $5 \mathrm{mg} / \mathrm{L}$. The culture was then incubated for 24 hours at $30^{\circ} \mathrm{C}$. Colonies isolated from the plates were purified and then Gram and spore stained were carried out for the further selection of bacteria in basal media.

\section{Sample analysis}

Measurement of temperature and Dissolved Oxygen (DO) using a DO meter (Krisbow KW0600752), pH using a pH meter (HANA HI 98107), measurements are carried out every day at $06.00 \mathrm{am}$. Ammonia and Total Organic Matter (TOM) are analyzed every 10 days at the Water Quality Laboratory of BBPBAP Jepara, Central Java, Indonesia, total bacteria (CFU/ml), abundance Vibrio sp. $(\mathrm{CFU} / \mathrm{ml})$, and total Bacillus subtilis (CFU/ml).

Measurement of seaworm growth is done every 10 days which includes: weight gain $(\mathrm{gr})$, length $(\mathrm{cm})$, total biomass (gr), total bacteria (CFU/ml), abundance Vibrio sp. $(\mathrm{CFU} / \mathrm{ml})$ and total Bacillus sp. (CFU/ml) in seaworms. The number of samples used in the measurement of growth was 5 individuals in each research container. Substrate excavation was carried out to obtain seaworm samples carried out at 5 different points, from corner and in the middle of the rearing container. Measurement of length and weight was carried out quickly, 3 seaworms from 5 samples in each of the measured study containers were then placed on a sterile Petri dish for intestinal collection. Seaworm samples were dissected using a sterilized dissecting set. Intestinal retrieval is carried out carefully.

\section{Production performance}

Production performance parameters for seaworms are determined according to the following: Standard length growth was observed every 10 days using Apriani et al. (11). The specific growth rate (SGR\%) was calculated every 10 days using Schulz et al. (1), Survival Rate (SR\%) was observed at the end of maintenance using the following Wiradana et al. (8), and the Biomass is the amount of animal biomass added over a certain period of time

\section{Data analysis}

The effect of each treatment on predetermined parameters has been tested with single-factor ANOVA at the 95\% confidence level. Duncan test to determine the best treatment. The software used is IBM SPSS version 25.0.

\section{Results}

\section{Water quality}

Water quality data including temperature, $\mathrm{pH}, \mathrm{DO}$, ammonia, TOM can be seen in Table 1. Temperature, $\mathrm{pH}$, and DO in each treatment and control showed high values so that the resulting value was not significant $(\mathrm{P}>0.05)$. The highest ammonia value was found at $\mathrm{P} 1(\mathrm{P}<0.05)$, indicating a significant difference with $\mathrm{P} 3$ but not significant with P2 and control $(\mathrm{P}>0.05)$. Based on the results of statistical tests on the TOM parameter, the highest value was found in P1 which in contrast showed a significant difference with control $(\mathrm{P}<0.05)$, while the $\mathrm{P} 2$ and $\mathrm{P} 3$ treatments did not show a significant value $(\mathrm{P}<0.05)$.

\section{Total water bacteria}

Data on total bacteria and total Bacillus subtilis in each treatment on seaworm rearing media can be seen in Table 2 . The total bacteria at P1, P2, and P3 showed insignificant differences $(\mathrm{P}>0.05)$ but all treatments when compared to controls. The predominant bacteria are the bacterium Bacillus subtilis. It shows that P3 is significantly different from control $(\mathrm{P}<0.05)$, while $\mathrm{P} 3$ is not significantly different from the other two treatments.

\section{Total water bacteria}

Data on total bacteria and total Bacillus subtilis in each treatment on seaworm rearing media can be seen in Table 2 . The total bacteria at P1, P2, and P3 showed insignificant differences $(\mathrm{P}>0.05)$ but all treatments when compared to controls. The predominant bacteria are the bacterium Bacillus subtilis. It shows that P3 is significantly different from control $(\mathrm{P}<0.05)$, while $\mathrm{P} 3$ is not significantly different from the other two treatments.

\section{Total gut bacteria}

Data on total bacteria count, Bacillus subtilis, and Vibrio sp. in each treatment in the intestines of seaworms can be seen in Table 3. The highest value on P1 and the lowest on Control showed insignificant differences $(\mathrm{P}>0.05)$. The values contained in $\mathrm{P} 1, \mathrm{P} 2$, and $\mathrm{P} 3$ are not significant difference $(\mathrm{P}>0.05)$. When compared, the total value of bacteria at $\mathrm{P} 1$ and $\mathrm{P} 3$ showed a significant difference $(\mathrm{P}<0.05)$. Although the total bacteria in $\mathrm{P} 3$ was low when compared to $\mathrm{P} 1$ and $\mathrm{P} 2$, the total Bacillus subtilis which was the dominant bacteria with a high value was found in P3, 
there was a significant difference between all treatments $(\mathrm{P}<0.05)$. Total Vibrio sp. at $\mathrm{P} 1$ was higher than the other treatments, with a total of Vibrio sp. lowest at $\mathrm{P} 3(\mathrm{P}<0.05)$ when compared to other treatments.

\section{Production performance parameters}

Production performance observations including final weight (Wt), Specific Growth Rate (SGR), standard length $(\mathrm{cm})$, survival rate (SR), and biomass (g) can be seen in table 4 . The $\mathrm{Wt}$, shows that there is no significant difference
( $>0.05)$ from the three treatments to the control. The highest SGR and Biomass values were found in P3 which showed a significant difference $(\mathrm{P}<0.05)$ when compared to the control and there was no significant difference between P1 and P2. The results of observations on the SR parameters and the standard length gain, P3 showed high values of all treatments. When compared, the $\mathrm{P} 3$ value to the control shows a significant difference $(\mathrm{P}<0.05)$, while it does not show a significant difference to other treatments.

Table 1: Physicochemical parameters of water

\begin{tabular}{lcccc}
\hline \multirow{2}{*}{ Parameters } & \multicolumn{4}{c}{ Treatments } \\
\cline { 2 - 5 } & P1 & P2 & P3 & Control \\
\hline Temperature $\left({ }^{\circ} \mathrm{C}\right)$ & $28.73 \pm 0.40^{\mathrm{a}}$ & $28.26 \pm 0.08^{\mathrm{a}}$ & $28.13 \pm 0.12^{\mathrm{a}}$ & $28.46 \pm 0.08^{\mathrm{a}}$ \\
pH & $6.5 \pm 0.05^{\mathrm{a}}$ & $6.4 \pm 0.08^{\mathrm{a}}$ & $6.4 \pm 0.05^{\mathrm{a}}$ & $6.5 \pm 0.05^{\mathrm{a}}$ \\
DO $(\mathrm{mg} / \mathrm{L})$ & $5.23 \pm 0.17^{\mathrm{a}}$ & $5.56 \pm 0.17^{\mathrm{a}}$ & $5.26 \pm 0.12^{\mathrm{a}}$ & $5.30 \pm 0.05^{\mathrm{a}}$ \\
Ammonia $(\mathrm{mg} / \mathrm{L})$ & $0.60 \pm 0.10^{\mathrm{b}}$ & $0.35 \pm 0.05^{\mathrm{ab}}$ & $0.31 \pm 0.06^{\mathrm{a}}$ & $0.39 \pm 0.05^{\mathrm{ab}}$ \\
TOM $(\mathrm{mg} / \mathrm{L})$ & $119.23 \pm 3.79^{\mathrm{b}}$ & $109.66 \pm 2.73^{\mathrm{ab}}$ & $104.66 \pm 5.22^{\mathrm{ab}}$ & $93.26 \pm 7.59^{\mathrm{a}}$ \\
\hline
\end{tabular}

*TOM: Total Organic Matter, DO: Dissolved oxygen. Data are displayed using the mean \pm SE (standard error). Mean on the same line with different manuscripts showed a significant difference $(\mathrm{P}<0.05)$.

Table 2: Total bacteria count and Bacillus subtilis count

\begin{tabular}{ccccc}
\hline \multirow{2}{*}{ Parameters } & \multicolumn{4}{c}{ Treatments } \\
\cline { 2 - 5 } & P1 & P2 & P3 & Control \\
\hline Total Bacteria count $\times 10^{5}(\mathrm{CFU} / \mathrm{ml})$ & $4.18 \pm 0.26^{\mathrm{b}}$ & $4.43 \pm 0.15^{\mathrm{b}}$ & $4.28 \pm 0.28^{\mathrm{b}}$ & $2.72 \pm 0.19^{\mathrm{a}}$ \\
Total Bacillus subtilis $\times 10^{3}(\mathrm{CFU} / \mathrm{ml})$ & $3.66 \pm 0.83^{\mathrm{ab}}$ & $5.11 \pm 0.77^{\mathrm{ab}}$ & $5.89 \pm 0.67^{\mathrm{b}}$ & $3.00 \pm 0.38^{\mathrm{a}}$ \\
\hline
\end{tabular}

Data are displayed using the mean \pm SE (standard error). Mean on the same line with different manuscripts showed a significant difference $(\mathrm{P}<0.05)$.

Table 3: Total Bacteria, Total Bacillus subtilis, and Total Vibrio sp. in the intestine of seaworms

\begin{tabular}{lcccc}
\hline \multirow{2}{*}{ Parameters } & \multicolumn{4}{c}{ Treatments } \\
\cline { 2 - 5 } & P1 & P2 & P3 & Control \\
\hline Total Bacteria Count $\times 10^{6}(\mathrm{CFU} / \mathrm{ml})$ & $5.74 \pm 067^{\mathrm{b}}$ & $5.49 \pm 0.56^{\mathrm{ab}}$ & $4.12 \pm 0.26^{\mathrm{a}}$ & $3.72 \pm 0.76^{\mathrm{b}}$ \\
Total Bacillus subtilis $\times 10^{4}(\mathrm{CFU} / \mathrm{ml})$ & $2.55 \pm 0.67^{\mathrm{a}}$ & $2.77 \pm 0.77^{\mathrm{a}}$ & $4.80 \pm 0.56^{\mathrm{b}}$ & $2.23 \pm 0.29^{\mathrm{a}}$ \\
Total Vibrio sp. $\times 10^{3}(\mathrm{CFU} / \mathrm{ml})$ & $3.82 \pm 0.62^{\mathrm{b}}$ & $2.90 \pm 0.35^{\mathrm{ab}}$ & $2.00 \pm 0.41^{\mathrm{a}}$ & $3.54 \pm 0.41^{\mathrm{ab}}$ \\
\hline
\end{tabular}

Data are displayed using the mean \pm SE (standard error). Mean on the same line with different manuscripts showed a significant difference $(\mathrm{P}<0.05)$.

Table 4: Production performance of seaworms after administration of the probiotic Bacillus subtilis

\begin{tabular}{lcccc}
\hline \multirow{2}{*}{ Parameters } & \multicolumn{4}{c}{ Treatments } \\
\cline { 2 - 5 } & $1.0 \pm 0.28^{\mathrm{a}}$ & $1.26 \pm 0.10^{\mathrm{b}}$ & $1.29 \pm 0.06^{\mathrm{b}}$ & $1.08 \pm 0.14^{\mathrm{ab}}$ \\
\hline $\mathrm{W}_{\mathrm{t}}(\mathrm{g})$ & $0.26 \pm 0.37^{\mathrm{ab}}$ & $0.86 \pm 0.06^{\mathrm{ab}}$ & $1.01 \pm 0.29^{\mathrm{b}}$ & $0.14 \pm 0.05^{\mathrm{a}}$ \\
$\mathrm{SGR}(\%)$ & $75.89 \pm 3.09^{\mathrm{a}}$ & $75.33 \pm 2.54^{\mathrm{a}}$ & $86.66 \pm 4.44^{\mathrm{b}}$ & $72.00 \pm 1.16^{\mathrm{a}}$ \\
$\mathrm{SR}(\%)$ & $1.53 \pm 0.29^{\mathrm{b}}$ & $2.03 \pm 0.16^{\mathrm{b}}$ & $3.07 \pm 0.34^{\mathrm{c}}$ & $0.66 \pm 0.10^{\mathrm{a}}$ \\
Standard length (cm) & $29.93 \pm 2.80^{\mathrm{ab}}$ & $31.80 \pm 2.48^{\mathrm{ab}}$ & $37.00 \pm 3.71^{\mathrm{b}}$ & $25.38 \pm 1.51^{\mathrm{a}}$ \\
Biomass $(\mathrm{g})$ & &
\end{tabular}

Data are displayed using the mean \pm SE (standard error). Mean on the same line with different manuscripts showed a significant difference $(\mathrm{P}<0.05)$. W $\mathrm{t}$ : Weight total, SGR: Specific Growth Ratio, SR: Survival Rate. 


\section{Discussion}

\section{Water quality}

The temperature and $\mathrm{pH}$ values in the maintenance media have been classified in the optimum range for seaworm cultivation. This is following previous research which states that the optimum temperature is $28-30.5^{\circ} \mathrm{C}$, the optimum value is $\mathrm{pH}$ 6-7 (1). Each treatment has a DO value ranging from $5.23-5.56 \mathrm{mg} / 1$. This value is not included in the optimum range based on previous research, which is 6-8 $\mathrm{mg}$ /l (2). However, this can still be tolerated by seaworms because, in natural habitats, seaworms can live in the DO range between 1.01-8.0 mg/l. Ammonia concentration and high temperature in the sludge medium were the causes of the decrease in DO in this study, which in turn was able to reduce growth and increase the mortality of experimental animals.

Based on TOM observations, at P1, P2 and P3 have values above the optimal average ranging from $55-95 \mathrm{mg} / \mathrm{l}$. The addition of molasses as a source of carbon and nitrogen affects the TOM value due to the addition of organic matter resulting in a buildup of organic matter such as remaining feed and animal waste. The decomposition of organic matter by heterotrophic bacteria on P1 takes place more slowly. In addition, seaworms are deposit feeders that consume sediment deposits, allowing them to use organic matter contained in sediments directly. Digestible organic matter consists of only $<1 \%$ based on the total sediment consumed (14).

Bacillus sp. a type of bacteria that can grow in various conditions and is saprophytic and can form endospores that remain active in the digestive tract (15). The endospores produced will remain active for a long period, so they are suitable for use as probiotic candidates. Ammonia value in each treatment exceeds the tolerance limit for aquatic biota, namely $0.01 \mathrm{mg} / \mathrm{l}$. High ammonia values can be caused by high density, namely 33 individuals/containers and high total organic matter (TOM). The ammonia concentration in P3 treatment is lower when compared to P1. This is due to the density of Bacillus subtilis different in each treatment which resulted in the performance of probiotics not optimal in degrading organic matter. The P3 treatment was able to reduce the ammonia concentration by $47.5 \%$ compared to the P1 treatment which was $37.8 \%$. This proves that the probiotic bacteria used can utilize inorganic nitrogen for cell growth and multiplication. According to Kim et al. (16), as much as $12.4 \%$ nitrogen contained in ammonium will be used for the addition of bacterial biomass. Furthermore, Ebeling et al. (17) stated that the ammonia that has been formed will be used by heterotrophic bacteria and synthesized into protein due to the presence of organic carbon compounds (such as sugar and molasses). Bacillus subtilis is a type of heterotrophic bacteria that will utilize $\mathrm{N}$ either in organic or inorganic form for the formation of bacterial biomass so that the concentration of $\mathrm{N}$ in water can be reduced.
In addition, water quality parameters such as temperature and $\mathrm{pH}$ have an important influence on the rate of ammonia concentration, namely the higher the $\mathrm{pH}$ and temperature, the ammonia levels and their toxicity tend to increase as found in the P1 treatment in this study. This is because at high temperatures and $\mathrm{pH}$ more nitrogen will be formed in the form of $\mathrm{NH}_{3}$ which is part of TAN.

\section{Abundance Vibrio sp. in sea worms with the use of the probiotic Bacillus subtilis}

Abundance Vibrio sp. shows a significant difference $(\mathrm{P}<0.05)$ in treatment $\mathrm{P} 1$ and $\mathrm{P} 3$. Treatment with probiotics showed that total Bacillus subtilis in treatment P3 could reduce the abundance of Vibrio sp by $75.90 \%$ compared to treatment P1. Abundance of Vibrio sp. can be influenced by the presence of the Bacillus subtilis which suppresses the growth of Vibrio sp. by producing metabolites in the digestive tract. Bacillus subtilis is used as a probiotic product in aquatic-terrestrial animals which will be active while in the digestive tract (18). Abundance Vibrio sp. in all treatments was $10^{3}$ which is still low while the infection threshold for Vibrio sp. is $10^{4}$ and likely will not cause vibriosis if seaworms are used as natural feed for shrimp broodstock (19). It can be explained that the Vibrio sp. depends on density and dominance in an environment and occurs naturally in all aquatic environments and is mostly found in shrimp farming.

\section{Production performance}

Based on the results of the study, it can be seen that the value of the final weight, SGR, SR, length, and biomass growth standard. In seaworms with the highest value is found in the P3 treatment when compared to other treatments. This can be caused by the use of the Bacillus subtilis bacteria as a probiotic agent capable of influencing the growth of seaworms. The probiotics given enter the digestive tract through water and stick to the host. The use of probiotics with Bacillus subtilis mixed in feed can stimulate growth in other aquatic biota. Probiotic applications can be in the form of mono strains (as was done in this study), multiple, or even in combination with prebiotics or better known as synbiotics. Encapsulation of probiotics with live feed is a good approach to convey the effectiveness of probiotics to aquatic animals (20). Digestive enzymes can be triggered by giving probiotics which can promote better growth than without probiotics. SGR and biomass values on P1 treatment and control were lower than those of other probiotic treatments. Low SGR can be caused by several reasons, such as feed quality and feeding habits and the health status of aquatic animals which can play an important role in determining SGR (21).

The results of the observation on the SR parameter (\%) showed that the P3 treatment had a greater value than all other treatments. The substrate used can affect survival in seaworm maintenance. The finer the substrate is used, the less energy use will be. Apart from the substrate, high 
ammonia levels can also affect survival in seaworm maintenance. Ammonia in the form of $\mathrm{NH}_{3}$ molecules can penetrate cell membranes faster and affect the physiology of organisms (22-24).

\section{Conclusion}

Probiotic application using the bacterial agent Bacillus subtilis with different densities able to provide a significant difference in the growth of seaworms. Apart from increasing growth, Bacillus subtilis as a probiotic agent is also able to reduce the number of pathogenic bacteria in the intestine. During this study, the best treatment was P3 treatment, namely probiotics with a density of $10^{6}$ bacteria to increase growth and reduce the pathogen Vibrio sp. Further research is needed to determine the activity of enzymes that occur in the intestines of marine worms in the application of probiotics, prebiotics, synbiotics and immunostimulants.

\section{Acknowledgment}

This study was supported by Jakarta Technical University of Fisheries and BBPBAP Jepara, Central Java, Indonesia. Thanks to Mrs. Ita Rizkiyanti as the field supervisor at the Microbiology Laboratory (BBPBAP Jepara, Central Java, Indonesia), KORAL AUP-STP at BBPBAP Jepara who has helped a lot during this research.

\section{Competing interests}

The authors declare that they have no competing interests.

\section{References}

1. Asnawi $Y$, Idris M. The influence of different substrates on the growth of sea worm (Nereis sp). Med Akuat. 2018;3:670-679. www.ejournalbalitbang.kkp.go.id

2. Meunpol O, Meejing P, Piyatiratitivorakul S. Maturation diet based on fatty acid content for male Penaeus monodon (Fabricius) broodstock. Aquac Res. 2005;36:1216-1225. DOI: $10.1111 / \mathrm{j} .1365-$ 2109.2005.01342.x

3. Wibowo ES, Yuwono E, Sukardi P, Siregar AS. Survival rate, growth and chemical content of Dendronereis pinnaticirris (Polychaeta, Nereidae) in maintenance with different food and substrate. J Mar Sci. 2020;25:75-84. DOI: 10.14710/ik.ijms.25.2.75-84

4. Camargo JA, Alonso A. Ecological and toxicological effects of inorganic nitrogen pollution in aquatic ecosystems: A global assessment. Environ Int. 2006;32:831-849. DOI: 10.1016/j.envint.2006.05.002

5. Yuhana M. Biocontrol agents in aquaculture: Production and their application. J Akuakultur Indonesia. 2010;1:16-20. DOI: 10.19027/jai.9.16-20

6. Mandario MAE. Addressing gaps in the culture of pathogen-free polychaetes as feed in shrimp hatcheries. Fish People. 2018;16:19-23. www.repository.seafdec.org.ph

7. Vijayan K, Stalin Raj V, Balasubramanian C, Alavandi S, Thillai Sekhar V, Santiago T. Polychaete worms; a vector for white spot syndrome virus (WSSV). Dis Aquat Organ. 2005;63:107-111. DOI: $\underline{10.3354 / \text { dao063107 }}$
8. Wiradana PA, Mahasri G, Sari RER, Marwiyah UC, Prihadhana R. Identification of white spot syndrome virus (WSSV) in pacific white shrimps (Litopenaeus vannamei) from ponds postexposure to immunogenic membrane proteins (Zoothamnium penaei). IOP Conf Ser Earth Environ Sci. 2019;236(1):1-10. DOI: 10.1088/17551315/236/1/012085

9. Thitamadee S, Prachumwat A, Srisala J, Jaroenlak P, Salachan PV, Sritunyalucksana K, Flegel TW, Itsathitphaisarn, O. Review of current disease threats for cultivated penaeid shrimp in Asia. Aquacul. 2016;452:69-87. DOI: 10.1016/j. aquaculture.2015.10.028

10. Verschuere L, Rombaut G, Sorgeloos P, Verstraete W. Probiotic bacteria as biological control agents in aquaculture. Microbiol Mol Biol Rev. 2000;64:655-671. DOI: 10.1128/MMBR.64.4.655-671.2000

11. Apriani I, Setiawati M, Budiardi T, Widanarni. Pangasianodon hypophthalmus (Sauvage 1878) juvenile production using biofloc technology with different carbon sources. J Iktiologi Indonesia. 2016;16:75-90. DOI: 10.32491/jii.v16i1.51

12. Schulz C, Knaus U, Wirth M, Rennert B. Effects of varying dietary fatty acid profile on growth performance, fatty acid, body and tissue composition of juvenile pike perch (Sander lucioperca). Aquac Nutr. 2005;11:403-413. DOI: 10.1111/j.1365-2095.2005.00369.x

13. Rasidi R. Know the type of sea worms and their cultivation opportunities for the provision of natural feed-in shrimp hatcheries Media Akuakultur. 2013;8:57. DOI: 10.15578/ma.8.1.2013.57-62

14. Shull DH. Bioturbation. In: Encyclopedia of Ocean Sciences. Netherlands: Elsevier; 2009. 395-400 p.

15. Earl AM, Losick R, Kolter R. Ecology and genomics of Bacillus subtilis. Trends Microbiol. 2008;16:269-275. DOI: 10.1016/j.tim.2008.03.004

16. Kim JK, Park KJ, Cho KS, Nam SW, Park TJ, Bajpai R. Aerobic nitrification-denitrification by heterotrophic Bacillus strains. Bioresour Technol. 2005;96:1897-1906. DOI: 10.1016/j.biortech.2005.01.040

17. Ebeling JM, Timmons MB, Bisogni JJ. Engineering analysis of the stoichiometry of photoautotrophic, autotrophic, and heterotrophic removal of ammonia-nitrogen in aquaculture systems. Aquacult. 2006;257:346-358. DOI: 10.1016/j.aquaculture.2006.03.019

18. Martinez Cruz P, Ibanez AL, Monroy Hermosillo OA, Ramirez HC. Use of probiotics in aquaculture. ISRN Microbiol. 2012:1-13. DOI: $10.5402 / 2012 / 916845$

19. Sani MD, Maharani AY, Riandy MI, Joko PA, Wiradana PA, Soegianto A. Monitoring of population density of Vibrio sp. and health condition of hepatopancreas Pacific white shrimp (Litopenaeus vannamei) cultivated with intensive systems in Bulukumba Regency, South Sulawesi, Indonesia. Eco Env Cons. 2020;26:1271-1275. www.envirobiotechjournals.com

20. Hai NV. The use of probiotics in aquaculture. J Appl Microbiol. 2015;119:917-935. DOI: $10.1111 / \mathrm{jam} .12886$

21. Arisa II, Widanarni W, Yuhana M, Muchlisin ZA, Abdullah AA. The application of probiotics, prebiotics and symbiotic to enhance the immune responses of vannamei shrimp (Litopenaeus vannamei) to Vibrio harveyi infection. AACL Bioflux. 2015;8:772-778. www.bioflux.com.ro

22. Taragusti A, Prayogo P, Rahardja B. The effect of stocking density and the application of Nitrobacter as ammonia decomposer in aquaponics system of Clarias gariepinus with water spinach (Ipomoea aquatica). Iraqi J Vet Sci. 2020 ;35:217-222. DOI: 10.33899/ijvs.2019.126116.1243

23. Fira D, Wiradana P, Ansori A, Susilo RJK, Sabdoningrum E. Ectoparasite inventorisation of nilem fish (Osteochilus hasselti) fingerlings cultured on ponds in Sukabumi, West Java, Indonesia. Iraqi J Vet Sci.2021;35:605-609. DOI: 10.33899/ijvs.2020.127031.1440

24. Fanni N, Shaleh F, Santanumurti M. The role of clove (Sygnium aromaticum) oil as anaesthetics compound for abalone (Haliotis squamata). Iraqi J Vet Sci. 2021;35:335-342. DOI: $\underline{10.33899 / \text { ijvs.2020.126824.1396 }}$ 
(غرام) والطول (سم) والكتلة الحيوية الكلية (غرام) و العدد الكلي

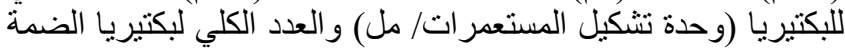

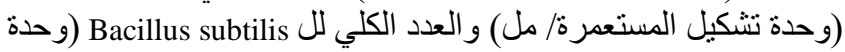

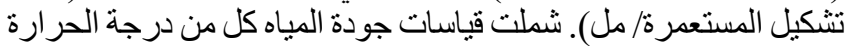

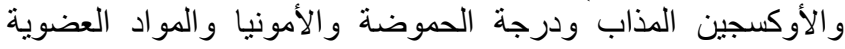

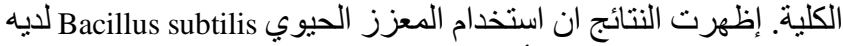
القدرة على تقليل تركيز الأمونيا وزيادة النمو و التقليل من وفرة بكتينيريا

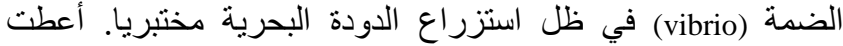

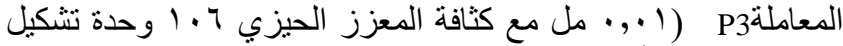

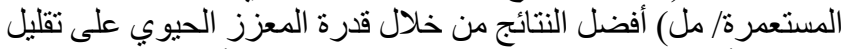

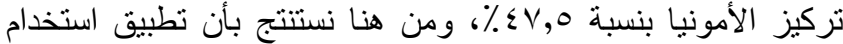

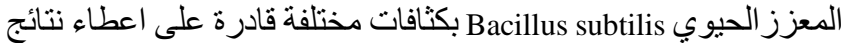
جيدة في دعم الأداء الإنتاجي و الحفاظ على وفرة بكتريا الضمة (vibrio)

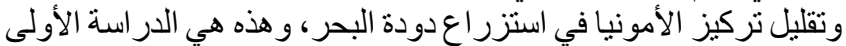

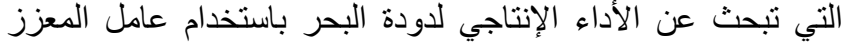

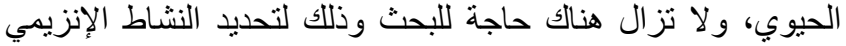

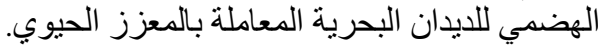

إمكانية المعزز الحيوي Bacillus subtilis في تقلئيل مستويات الأمونيا وتوافر انواع بكتيريا الضمة وزياديادة الأداء الإنتاج لاودة البحر مختبريا

أديتيا كامارودين'، موش نور الهدى'، دجومبا روكمونو' و أنكا ورادانـان أنائ

' قسم الاحياء المائية، كلية الموارد السمكية، جامعة جاكرنا للموارد

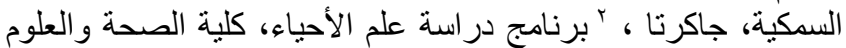
و التكنولوجيا، جامعة دهيانا بور ا، بالي ، برجية إندونيسيا

الخلاصة

تهدف هذه الدر اسة إلى إمكانية المعزز الحيوي Bacillus subtilis في

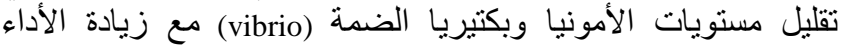

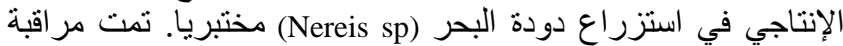

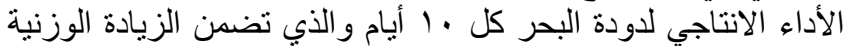

